\title{
Longleaf pine proximity effects on air temperatures and hardwood top-kill from prescribed fire
}

\author{
Seth W. Bigelow *iD and Andrew W. Whelan
}

\begin{abstract}
Background: Regulation of the dominance of resprouting understory hardwoods is a common objective for prescribed fire in open-canopy longleaf pine (Pinus palustris Mill.) woodland of the southeastern USA. Nevertheless, little is known about the influence of individual pines on fire and hardwood mortality. We studied growing-season fires in stem-mapped stands in southwest Georgia, USA; the stands displayed large variation in structure due to cutting treatments applied seven years earlier. We measured air temperature and heating duration, and measured post-fire sprouting behavior of four guilds of understory hardwoods: mesic oaks (Quercus spp. L.), upland oaks, xeric oaks, and fleshy-fruited hardwoods. Mean air temperature (i.e., of flames, buoyant plume, and smoldering combustion) and heating duration (time over $60^{\circ} \mathrm{C}$ ) were analyzed with respect to fuel-bed conditions and neighboring tree density. Hardwood top-kill was analyzed with respect to neighboring tree density and hardwood height.

Results: The basal area of nearby pines strongly affected heating duration (time over $60^{\circ} \mathrm{C}$ ), which increased linearly from a mean of $87 \mathrm{~s}$ to a mean of $234 \mathrm{~s}$ across a gradient of pine basal area from 0 to $30 \mathrm{~m}^{2} \mathrm{ha}^{-1}$. Mean air temperature during prescribed fire was unaffected by pine density but increased linearly from a mean of $114^{\circ} \mathrm{C}$ to a mean of $148{ }^{\circ} \mathrm{C}$ across a gradient of wiregrass (Aristida stricta Michx.) cover from 0 to $100 \%$, respectively. Neighborhood models showed that time over $60^{\circ} \mathrm{C}$ during the burns was longest at the base of pines and decreased by two thirds at $3.3 \mathrm{~m}$ distance. Pines affected hardwood top-kill probability at a similar scale, the effect at $4.4 \mathrm{~m}$ decreasing by two thirds compared to at the base of the pine. The four hardwood guilds were readily top-killed when $\leq 1 \mathrm{~m}$ tall, but at $2 \mathrm{~m}$ height, upland and xeric oaks had become more resistant to top-kill than mesic oaks or fleshy-fruited hardwoods.

Conclusions: The influence of individual pine trees on heating duration and top-kill power of prescribed fire drops by two thirds of maximum within 3 to $4 \mathrm{~m}$ of a tree, compared to a maximum at the base of the tree. Neighborhood models provide a method to estimate tree effects on prescribed fire heating duration and top-kill probability, and thus a way of predicting stand structures that provide ecological benefits of openings while remaining below thresholds that trigger vigorous hardwood response.
\end{abstract}

Keywords: controlled burn, maximum likelihood, neighborhood methods, residence time, spatial influence model, thermocouple

\footnotetext{
* Correspondence: seth.bigelow@jonesctr.org

Jones Center at Ichauway, 3988 Jones Center Drive, Newton, GA 39870, USA
} 


\section{Resumen}

Antecedentes: La regulación de la dominancia de especies de madera dura rebrotantes del sotobosque es un objetivo común de las quemas prescriptas en bosques abiertos del pino de hoja larga (Pinus palustris Mill.), en el sudoeste de los EEUU. Sin embargo, es poco conocida la influencia individual de los pinos en la mortalidad de las especies de madera dura. Estudiamos incendios ocurridos durante la estación de crecimiento en rodales mapeados mediante el conteo de troncos en el sudoeste de Georgia, EEUU. Los rodales mostraron una gran variación en estructura debido a la aplicación de cortas siete años antes. Medimos la temperatura del aire y la duración del calentamiento en quemas prescriptas, y también el comportamiento de los rebrotes post-fuego de cuatro gremios de especies de madera dura del sotobosque: robles mésicos (Quercus spp. L.), robles de altura, robles xéricos, y especies de madera dura de frutos carnosos. La temperatura media del aire (i.e., de las llamas, de su pluma, y de la combustión latente), y la duración del calentamiento (tiempo en que temperatura fue mayor de $60^{\circ} \mathrm{C}$ ) fueron analizados en relación a las condiciones de la cama de combustibles y la densidad de árboles vecinos. La muerte apical de las especies de madera dura fue analizada en relación a la densidad de árboles vecinos y la altura de las especies de madera dura.

Resultados: El área basal de los pinos vecinos afectaron fuertemente la duración del calentamiento (tiempo por encima de los $60^{\circ} \mathrm{C}$ ), que se incrementó de manera lineal de una media de $87 \mathrm{~s}$ a una media de $234 \mathrm{~s}$ a través del gradiente de área basal de 0 a $30 \mathrm{~m}^{2} \mathrm{ha}^{-1}$. La temperatura media del aire durante las quemas prescriptas no fue afectada por la densidad de pinos, pero se incrementó linealmente de una media de $114{ }^{\circ} \mathrm{C}$ a una media de $148{ }^{\circ} \mathrm{C}$ al incrementarse gradualmente la cobertura del pasto alambre (Aristida stricta Michx.) del 0 al 100\%,

respectivamente. Los modelos de parcelas vecinas mostraron que la duración del calentamiento por encima de los $60{ }^{\circ} \mathrm{C}$ durante las quemas fue mayor en la base de los pinos y decreció por dos tercios a una distancia de 3,3 m. Los pinos afectaron la probabilidad de muerte apical de las especies de madera dura en una escala similar, es decir el efecto a 4,4 m decreció por dos tercios comparado con la base de los pinos. Los cuatro gremios de especies de madera dura fueron rápidamente afectados por muerte apical cuando su altura fue $\leq 1 \mathrm{~m}$, pero cuando llegaban a los $2 \mathrm{~m}$ de altura, los robles de altura y los xéricos fueron más resistentes a la muerte apical que los robles mésicos o que las especies de madera dura de frutos carnosos.

Conclusiones: La influencia de los pinos individuales sobre la duración del calentamiento y el poder de producir la muerte apical mediante quemas prescriptas bajó a dos tercios del máximo entre los 3 a $4 \mathrm{~m}$ de un árbol comparado con el máximo en la base del árbol. Los modelos de parcelas vecinas proveen de un método para estimar los efectos de los árboles en la duración del calentamiento durante las quemas prescriptas y en la probabilidad de muerte apical, y sirven como un modo de predecir las estructuras de los rodales que proveen los beneficios ecológicos de las aperturas de los doseles, mientras permanecen por debajo de los límites que desencadenan un vigoroso rebrote de las especies de madera dura del sotobosque.

\section{Abbreviations}

AICc: Akaike's Information Criterion corrected for small sample size

dbh: Diameter at breast height

NDI: Neighborhood Density Index

$\Delta_{\mathrm{i}}$ : Difference between model AIC and AIC of the best model

$\mathrm{R}^{2}$ : Coefficient of determination

Adjusted $R^{2}$ : Proportion of variance explained by nonlinear regression model relative to the simple mean of the dependent variable

\section{Background}

Frequent fire is a keystone process in longleaf pine (Pinus palustris Mill.) forests, maintaining open conditions that perpetuate the extraordinarily high herbaceous plant diversity of the Southeastern Coastal Plain (Thaxton and Platt 2006; Dell et al. 2017; Kirkman and Giencke 2017). Fire is particularly important for regulating the dominance of oaks (Quercus spp. L.) and other broadleaved resprouting trees (henceforth, hardwoods), which often are present in high numbers in the understory of these forests (Provencher et al. 2001; Whelan et al. 2018). Pines provide fuel for prescribed fire through their shed needles, and careful selection of trees for harvest to maintain an evenly distributed rain of needles is a central element of ecological silviculture (Mitchell et al. 2009; Neel et al. 2010). Nevertheless, there are scant data and analyses directly linking pine spacing to fire conditions and hardwood control (Rebertus et al. 1989).

Longleaf needles have distinctive characteristics as fuel, stemming from their high energy content (Reid and Robertson 2012; Ellair and Platt 2013). Longleaf needles have high 
concentrations of terpenes, which are associated with high flame temperatures (Ormeño et al. 2009). Some in situ studies have found only minor effects of longleaf pine density on air temperature during prescribed fire (Kennard and Outcalt 2006; Loudermilk et al. 2012), but one study showed a strong relationship between fire radiative energy release and proximity of longleaf pine trees ( $\mathrm{O}^{\prime}$ Brien et al. 2016). Canopy-derived surface fuels fall in a predictable spatial pattern around trees (Ferrari and Sugita 1996; Bigelow and Canham 2015), potentially creating a consistent spatial pattern of longleaf pine on fire properties.

Neighborhood analyses link tree species population dynamics to ecosystem processes (Canham et al. 2006). A neighborhood analysis requires specifying the functional form of an individual tree's influence on a process, and the functional form must incorporate both the effect of tree size and the attenuation of the effect with distance. Parameters for neighborhood models are estimated in an inverse fashion using point data in mapped stands: the most-likely parameters are those that provide the best fit of model to data (Burnham and Anderson 2002). Model evaluation is accomplished by comparing alternative functional forms. Neighborhood analyses have been used to determine the spatial influence of individual trees on processes such as nutrient cycling, seed dispersal, and leaf dispersal (Pacala et al. 1996; Bigelow and Canham 2015, 2017), but have seen little or no use in fire-related studies.

One important goal of prescribed fire in longleaf pine forests, regulation of hardwood dominance, involves heating the vascular cambium so that aboveground parts die (i.e., undergo top-kill). If stem cambial heating results in cell death, subsequent sprouting must occur near the ground rather than higher up on the stem (Robertson and Hmielowski 2014). The hardwood is thereby maintained in a subordinate canopy position where it remains vulnerable to subsequent fires (Bond and Midgley 2000; Grady and Hoffman 2012). When stem cambium temperature has reached $60{ }^{\circ} \mathrm{C}$ during simulated surface fires, cambial cell mortality is complete (Dickinson and Johnson 2004); however, an air temperature of $60{ }^{\circ} \mathrm{C}$ should not be interpreted as equivalent to cambial temperature of $60{ }^{\circ} \mathrm{C}$, particularly because bark insulates cambium, slowing the conduction of heat from the bark surface. Both air temperature during fire (i.e., temperature of flames, buoyant plume, and smoldering combustion) and residence time (duration of heating) are indicators of a fire's ability to transfer heat to stem cambium (Dickinson and Johnson 2001).

Hardwood trees (defined here as eudicots and magnoliids that can grow unsupported to a height of $15 \mathrm{~m}$ ) vary in their vulnerability to top-kill depending on bark characteristics and other features. Common hardwoods of upland (as opposed to flatwood, sandhill, or mountain; Boring et al.
2017) longleaf pine forest can be classified in guilds defined by trait associations of habitat, physiology, phylogeny, and flammability (Cavender-Bares et al. 2004; Varner et al. 2016). The mesic oaks occur on wet sites as well as upland sites, have leaves that burn poorly, and are evergreen or lose their leaves only briefly before replacing them. These include water oak (Quercus nigra L.), laurel oak (Q. hemisphaerica Bart. ex Wild.), and live oak (Q. virginiana Mill.). The upland oaks occur on drier sites, have more flammable leaves, and are deciduous. These include southern red oak (Q. falcata Michx.) and post oak (Q. stellata Wangenh.). The xeric oaks bluejack oak (Q. incana Bartr.), sand post oak (Q. margaretta Ashe), and turkey oak (Q. laevis Walt) are most abundant on deep sands, have flammable leaves, and are deciduous. Beyond the oaks there are several hardwood species with fleshy fruits, including sassafras (Sassafras albidum [Nutt.] Nees), persimmon (Diospyros virginiana L.), and black cherry (Prunus serotina Ehrh.). These hardwood guilds differ in the allometric relationship between bark thickness and height and, consequently, in their tolerance of prescribed fire (Jackson et al. 1999; Graves et al. 2014).

Top-kill will generally occur if flames from prescribed fire are able to reach the base of the understory hardwood (Robertson and Ostertag 2007). Lack of fine fuels due to a paucity of pine trees and the presence of low-flammability hardwood leaves may prevent flames from reaching a hardwood (O'Brien et al. 2008). Spatial influence models offer the prospect of inferring fuelbed continuity from knowledge of overstory tree spatial distribution. We wished to know how the spatial scale of top-kill varies in concert with the spatial scale of prescribed fire behavior, based on the surrounding longleaf canopy. We posed two questions based on the varying combinations of tree sizes and distances (neighborhoods) created by replicated silvicultural treatments in a second-growth longleaf pine forest in southwest Georgia, USA. First, what is the spatial pattern of an individual longleaf pine's influence on prescribed fire temperature and duration? Second, what is the spatial pattern of an individual longleaf pine's influence on top-kill probability of four hardwood guilds? Resolving these uncertainties will improve the ability to link fire behavior with individual trees and make it easier to develop models for regulating hardwood dominance.

\section{Methods}

\section{Study site}

The study took place at The Jones Center at Ichauway, in Baker County, Georgia, USA (31.233 N, 84.467 W; elevation $50 \mathrm{~m}$ ). The area is within the Gulf Coastal Plain physiographic province. The climate is humid continental, and forest structure is open-canopy woodland, with typical stand basal area of $13 \mathrm{~m}^{2} \mathrm{ha}^{-1}$ (Holland et 
al. 2019). Most trees were second-growth longleaf pine that recruited to the canopy after timber harvest early in the twentieth century (Pederson et al. 2008). An understory of hardwood sprouts $<2 \mathrm{~m}$ height was present as clusters emanating from rootstocks whose density was estimated at 1000 to $2000 \mathrm{ha}^{-1}$ (Whelan et al. 2018). The ground cover was dominated by wiregrass (Aristida stricta Michx.) and included other perennial warm season bunchgrasses and many forbs; typical ground cover standing crop was $0.1 \mathrm{~kg} \mathrm{~m}^{-2}$ (Kirkman et al. 2016). The forest was managed with prescribed fire on a two-year return interval.

The study was done in forest plots of an ongoing experiment occupying 72 ha (Bigelow et al. 2018) that is testing three forms of uneven-aged forest management in which harvested trees are selected (1) individually ("single-tree selection"), (2) in small groups up to 0.2 ha ("group selection"), or (3) in small groups up to 0.4 ha in which exemplary trees were not cut ("group selection with reserves"; Franklin et al. 2007). The plots were used to provide variation in forest structure for regression analyses, and effects of the treatments themselves were not analyzed. Trees $\geq 10 \mathrm{~cm}$ diameter at breast height (dbh) were mapped with a geographic positioning system (Trimble Nomad with antenna, Trimble, Sunnyvale, California, USA) accurate to $<1 \mathrm{~m}$, in conjunction with compass and rangefinder; tree sizes and locations used in the study were measured in 2014. Longleaf pine was dominant, and had basal area from 8.7 to $15.4 \mathrm{~m}^{2} \mathrm{ha}^{-1}$, but southern red oak and post oak made up 4 to $5 \%$ of stand basal area on average. The logging treatments were applied in 2009; prescribed burns were done prior to timber harvest in 2009, then biennially starting in 2010. Burns of 2016 were the basis of our study.

\section{Experimental design and sampling of fire temperature}

Thermocouple deployment was intended to characterize air temperature and heating duration during prescribed fire to allow inference about top-kill of resprouting hardwoods. Air temperature was presumed to reflect prescribed fire flames, buoyant plume, and smoldering combustion. A measurement height of $0.5 \mathrm{~m}$ was selected as being relevant to tree stem cambial necrosis while remaining above the average height of ground cover vegetation (cf., Butler et al. 2016). Thermocouple wire was threaded through protective, flexible conduit attached to a metal fence pole bent at a right angle so that the thermocouple bead could be suspended over the fuel bed without any mounting apparatus beneath it. The thermocouple bead protruded horizontally $0.1 \mathrm{~m}$ beyond the mouth of the conduit. Thermocouples were made from 30-gauge chromel-alumel wire (K-type wire, temperature range -260 to $1370{ }^{\circ} \mathrm{C}$; Omega Engineering, Norwalk, Connecticut, USA.); bead diameter was $0.4 \mathrm{~mm}$.
Each thermocouple was connected to a buried datalogger (Hobo UX100-14M ${ }^{1}$ or UX120-14M or Campbell Scientific CR $1000^{2}$ ) by K-type wire and connectors.

Thermocouples were placed in the field prior to four prescribed burns in May 2016: up to 42 thermocouples were deployed for each burn. Thermocouple placement was stratified by overstory density in the 4 ha experimental plots using maps of Overstory Abundance Index (OAI) calculated on a $4 \mathrm{~m}$ grid by locating trees within $15 \mathrm{~m}$ of grid points and summing the quotient of basal area and distance from grid point (Palik et al. 2003). Thermocouples were placed in eight OAI classes spanning 0 to $1.43 \mathrm{~m}^{2} \mathrm{~m}^{-1}$. If silvicultural openings were present (i.e., in group selection and group selection with reserves treatment plots), three thermocouples were placed in each opening. One of the three thermocouples was placed at a randomly selected point along the opening edge (identified as a straight line between nearest edge trees), and the other thermocouples were placed 10 and $20 \mathrm{~m}$ distant in a line toward the center of the opening.

Several forest structure and ground cover measurements were taken at thermocouple locations as explanatory variables. Within a $1 \mathrm{~m}$ radius of plot center, we recorded mean height of herbaceous fuels and surface woody fuels, number of stems of hardwood trees with height $>1.37 \mathrm{~m}$ and $\mathrm{dbh}<10 \mathrm{~cm}$, and wiregrass cover (visually estimated in 10\% increments). Local basal area was estimated with prism of $2.3 \mathrm{~m}^{2} \mathrm{ha}^{-1}\left(10 \mathrm{ft}^{2} \mathrm{acre}^{-1}\right)$ basal area factor.

\section{During-burn measurements}

Prescribed fires were set in May 2016 using electricpump-driven drip torches mounted on all-terrain vehicles (Table 1). A backfire on the downwind boundary was set first, and after this boundary was secure, flanking and strip head fires were set. Data logger recording interval was $10 \mathrm{~min}$ when temperature was $<40{ }^{\circ} \mathrm{C}$ and dropped to $2 \mathrm{~s}$ once temperature reached $40{ }^{\circ} \mathrm{C}$. Rate of spread $\left(\mathrm{m} \mathrm{s}^{-1}\right)$ was estimated from fire transit time between sensors by making a three-dimensional graph of flame-front arrival times on universal transverse Mercator coordinates, creating a linear model of flame-front arrival time with respect to the coordinates, and taking the inverse of the linear model coefficient that corresponded most closely with the predominant direction of spread as seen on the graph. Wiregrass moisture was obtained at $1 \mathrm{hr}$ intervals by clipping two samples of live wiregrass (one from a sun-exposed position and the other from a shaded position), sealing in tins, weighing the same day, then drying at $60{ }^{\circ} \mathrm{C}$ for $48 \mathrm{hr}$ and

\footnotetext{
${ }^{1}$ Onset Computer Corporation, Bourne, Massachusetts, USA

${ }^{2}$ Campbell Scientific, Inc., Logan, Utah, USA.
} 
Table 1 Microclimatic conditions during four 2016 prescribed fires in longleaf pine forest in southwest Georgia, USA ${ }^{\dagger}$. Treatments include the following silvicultural treatments: $\mathrm{g}=$ group selection, $\mathrm{r}=$ group selection with reserves, $\mathrm{s}=$ single-tree selection, $\mathrm{c}=$ control. Time = period when fire burned, $\mathrm{RH}=$ relative humidity, $\mathrm{T}=$ air temperature, Gust $=$ maximum wind speed recorded per $3 \mathrm{~s}$ recording intervals, ROS = rate of spread of fire, and $\mathrm{P}=$ number of days since last precipitation

\begin{tabular}{|c|c|c|c|c|c|c|c|c|c|}
\hline 2006 date & $\begin{array}{l}\text { Burn area } \\
\text { (ha) }\end{array}$ & Treatment & $\begin{array}{l}\text { Time } \\
\text { (hhmm) }\end{array}$ & $\begin{array}{l}\mathrm{RH} \\
(\%) \\
\end{array}$ & $\begin{array}{l}\mathrm{T} \\
\left({ }^{\circ} \mathrm{C}\right) \\
\end{array}$ & $\begin{array}{l}\text { Wind speed } \\
\left(\mathrm{m} \mathrm{s}^{-1}\right)\end{array}$ & $\begin{array}{l}\text { Gust } \\
\left(\mathrm{m} \mathrm{s}^{-1}\right)\end{array}$ & $\begin{array}{l}\text { ROS } \\
\left(\mathrm{m} \mathrm{s}^{-1}\right)\end{array}$ & $\begin{array}{l}P \\
\text { (d) }\end{array}$ \\
\hline 2 May & 66 & rsc & 1024 to 1324 & 57 & 27.9 & 0.3 & 1.0 & 0.07 & 13 \\
\hline 6 May & 173 & gr & 1016 to 1158 & 49 & 17.5 & 0.8 & 2.3 & 0.32 & 4 \\
\hline 11 May & 42 & grs & 0958 to 1100 & 54 & 26.6 & 0.4 & 1.1 & 0.46 & 5 \\
\hline 23 May & 55 & gcs & 1141 to 1225 & 42 & 24.5 & 0.5 & 2.6 & 0.41 & 5 \\
\hline
\end{tabular}

${ }^{\dagger}$ US Climate Reference Network stations GA Newton 11 SW, <1 km from site of burn (https://www.ncdc.noaa.gov/crn)

weighing again. Meteorological data were obtained from equipment within $1 \mathrm{~km}$ of the study sites, US Climate Reference Network stations GA Newton 11 SW (https://www.ncdc.noaa.gov/crn). Meteorological data consisted of air temperature, relative humidity, wind speed, gust speed, and number of days since last rain.

\section{Analysis of air temperature and heating duration of prescribed fires}

One goal of the study was to explore the influence of spacing and size of longleaf pines on prescribed fire behavior. Mean air temperature (average of temperatures $>60{ }^{\circ} \mathrm{C}$ measured during passage of flaming fire front) and heating duration (time over $60{ }^{\circ} \mathrm{C}$ ) were selected as prescribed fire response variables because they are components of the heat transfer equation and can be used to predict vascular cambium necrosis of trees (Dickinson and Johnson 2004). To quantify the effect of highly localized understory variables compared to overstory, we performed multiple linear regression and relative importance analysis. Relative importance analysis shows the contribution of each independent variable to the multiple $\mathrm{R}^{2}$ (Grömping 2006). Explanatory variables were forest structure elements measured at thermocouple locations and moisture of the wiregrass sample taken nearest in time to when temperature of a thermocouple first exceeded $40{ }^{\circ} \mathrm{C}$.

Further analysis of fire metrics was carried out with maximum likelihood, using models of time over $60{ }^{\circ} \mathrm{C}$ with respect to distance from neighboring longleaf pine trees, size of the pine trees, wiregrass cover, and wiregrass moisture. A neighborhood density index $\left(N D I=\Sigma d b h^{2} \exp [-\gamma \cdot\right.$ dist $\left.]\right)$ was created by taking the squared $d b h$ (scaled in units of $\mathrm{m}$ ) of each tree within $20 \mathrm{~m}$ of a thermocouple, weighting by distance (dist, scaled in units of decameters, i.e., tens of meters) according to a negative exponential function (in which the coefficient $\gamma$ is estimated from data), and summing. Heating duration was estimated from the equation
Time over $60^{\circ} \mathrm{C}=Y_{\mathrm{int}}+\lambda \cdot N D I$,

in which the coefficient $\lambda$ is a multiplier for $N D I$, and $Y_{\text {int }}$ is the intercept. A negative exponential function expresses a monotonic decrease in influence with increasing distance from a particular longleaf pine tree (Canham and Uriarte 2006). Because there were few mature oaks in the plots, they were included with the longleaf pines. The normal error distribution was used, which requires estimation of an additional parameter for the standard deviation. Variations on the basic model were created by including wiregrass cover and moisture as additive terms. An intercept-only model with no independent variables provided a baseline against which to compare more complex models.

We evaluated model parameter ranges to find values that provided best agreement with observations, using simulated annealing as a global optimization method (Bolker 2008). Model selection was based on parsimony using sample-size-corrected Akaike's information criterion (AICc). Models within 2 AICc units of the minimum were considered to have the same support as the AICc-best model; support intervals of \pm 2 AICc units, analogous to $95 \%$ confidence intervals, were reported. Reported values were obtained after $10^{5}$ iterations. We reported number of parameters, $\log$ of maximum likelihood, adjusted $\mathrm{R}^{2}$, AICc, and $\Delta_{\mathrm{i}}$ (difference between AICc and AICc minimum) for each model. Analyses were done in R statistical software with the Likelihood package (Murphy 2015; R Development Core Team 2016).

\section{Post-burn sprouting survey}

We conducted post-burn assessments of shrub-form hardwoods in July and August 2016 at 931 circular 2 m radius sample plots that were randomly selected in a geographic information system from throughout the control and single-tree selection plots, and in silvicultural openings in the group and group with reserves 
plots. Typically, live stems of established shrub-form hardwoods are not fully consumed by prescribed fire (Whelan et al. 2018), so we were able to identify stems that originated before the prescribed fire. In each $2 \mathrm{~m}$ radius plot, we located clumps of stems from 0.5 to $5 \mathrm{~m}$ tall presumed to have emerged from a common rootstock (genet) prior to the fire; identified the species and counted the stems; and visually estimated height of the tallest stem to the nearest $0.33 \mathrm{~m}$. If fire had burned through the $2 \mathrm{~m}$ radius plot, we visually estimated scorch height (via leaf discoloration) on the tallest stem per genet. We also noted if resprouting had occurred at the base or the crown of each clump. Non-resprouting, completely scorched plants were presumed dead. For analysis, we combined top-killed and dead plants in one group, and plants that escaped top-kill (either because they were incompletely scorched or because they resprouted from within the crown) in a second group.

\section{Spatial analysis of top-kill}

We asked how top-kill was affected by proximity to longleaf pines, using a maximum likelihood approach in which proximity to pines (expressed by NDI, defined as in Equation 1) was linked to a Michaelis-Menten or logistic top-kill probability function. Each function allowed probability of top-kill $(\operatorname{Pr}($ top-kill $))$ to increase from 0 to 1 as NDI increased. The Michaelis-Menten top-kill probability function,

$$
\operatorname{Pr}(\text { top }-k i l l)=\frac{A \cdot N D I}{\frac{A}{S}+N D I},
$$

increases with a slope of $S$ when $N D I$ is close to zero, then tapers off and approaches an asymptote $A$ as NDI increases. The logistic probability function,

$$
\operatorname{Pr}(\text { top }-k i l l)=\frac{1}{1+e^{-(\mathrm{a}+\mathrm{bNDI})}},
$$

produces a sigmoid curve defined by the parameters $a$ and $b$. The inflection point, at which top-kill probability is 0.5 , occurs at NDI $=-a b^{-1}$ (Bolker 2008). The binomial error distribution was used with both functions, and AICc was used to select the most parsimonious model. To test whether hardwood guilds behaved differently, AICc estimated when all hardwoods were treated as a single group was compared with AICc when hardwoods were separated into four guilds with their own parameters. Preliminary analyses showed that taller hardwoods were less likely to be top-killed, so hardwood height $(h t)$, raised to the exponent $-c$, was used as a multiplier of the NDI term in the Michaelis-Menten and logistic functions (MacFarlane and Kobe 2006). As height increases, the term $h t^{-c}$ becomes smaller and predicted top-kill probability decreases; the value of the parameter $c$ is estimated from the data. To determine the importance of hardwood height versus pine density as top-kill predictors, we evaluated models in which the power function of height, $h t^{-\mathrm{c}}$, appeared without NDI in the Michaelis-Menten and logistic functions. Again, a single $c$ parameter was estimated for hardwoods as a group, then $c$ was estimated for each of the four hardwood guilds.

\section{Results}

Factors affecting air temperature and time over $60^{\circ} \mathrm{C}$ during prescribed fire

Relative importance analysis indicated that measured variables accounted for $24 \%$ of variation in mean air temperature, $26 \%$ of variation in time over $60{ }^{\circ} \mathrm{C}$, and $33 \%$ of variation in a synthetic variable combining these fire behavior metrics (Table 2). Different factors influenced the two fire behavior metrics. Time over $60^{\circ} \mathrm{C}$ (s) was best explained by local basal area $\left(\mathrm{BA} ; \mathrm{m}^{2} \mathrm{ha}^{-1}\right)$ as estimated with a prism centered on the thermocouple (17\% of variation; Fig. 1); the simple linear regression was

$$
\text { Time over } 60^{\circ} \mathrm{C}=87.1+4.89 \cdot B A
$$

Wiregrass cover and moisture each explained 3\% of variation in time over $60{ }^{\circ} \mathrm{C}$. Mean air temperature $\left(T_{\text {mean }} ;{ }^{\circ} \mathrm{C}\right)$ was best explained by percent wiregrass cover ( $16 \%$ of variation; Fig. 2 ); the simple linear regression was $T_{\text {mean }}=114+0.34$ cover. Other variables such

Table 2 Relative importance (non-normalized contribution to multiple- $\mathrm{R}^{2}$ from multiple linear regression) of explanatory variables measured at thermocouple locations prior to prescribed burns in longleaf pine forest in southwest Georgia, USA, in May 2016; response variables are prescribed burn average temperature $\left(T_{\text {avg }}\right)$, time over $60^{\circ} \mathrm{C}\left(>60^{\circ} \mathrm{C}\right)$, and their product $\left(T_{\text {avg }}>60^{\circ} \mathrm{C}\right)$. Bold font highlights relative importance values $\geq 0.1$

\begin{tabular}{llll}
\hline & \multicolumn{3}{l}{ Relative importance } \\
\cline { 2 - 4 } Factor & $\mathrm{T}_{\text {avg }}$ & $>60{ }^{\circ} \mathrm{C}$ & $\mathrm{T}_{\text {avg }}>60{ }^{\circ} \mathrm{C}$ \\
\hline Point basal area $\left(\mathrm{m}^{2} \mathrm{ha}^{-1}\right)$ & 0.006 & $\mathbf{0 . 1 7 4}$ & $\mathbf{0 . 1 3 8}$ \\
Wiregrass cover (\%) & $\mathbf{0 . 1 7 1}$ & 0.029 & $\mathbf{0 . 1 4 0}$ \\
Herb height $(\mathrm{m})$ & 0.030 & 0.009 & 0.023 \\
Shrub height $(\mathrm{m})$ & 0.020 & 0.002 & 0.005 \\
Tree count $(n)$ & 0.001 & 0.010 & 0.004 \\
Wiregrass moisture $\left(\mathrm{g} \mathrm{g}^{-1}\right)$ & 0.007 & 0.033 & 0.008 \\
Basal area * wiregrass $\left(\mathrm{m}^{2} \mathrm{ha}^{-1}\right.$ * \%) & 0.002 & 0.001 & 0.008 \\
Sum (= multiple $\left.\mathrm{R}^{2}\right)$ & 0.240 & 0.258 & 0.322 \\
\hline
\end{tabular}



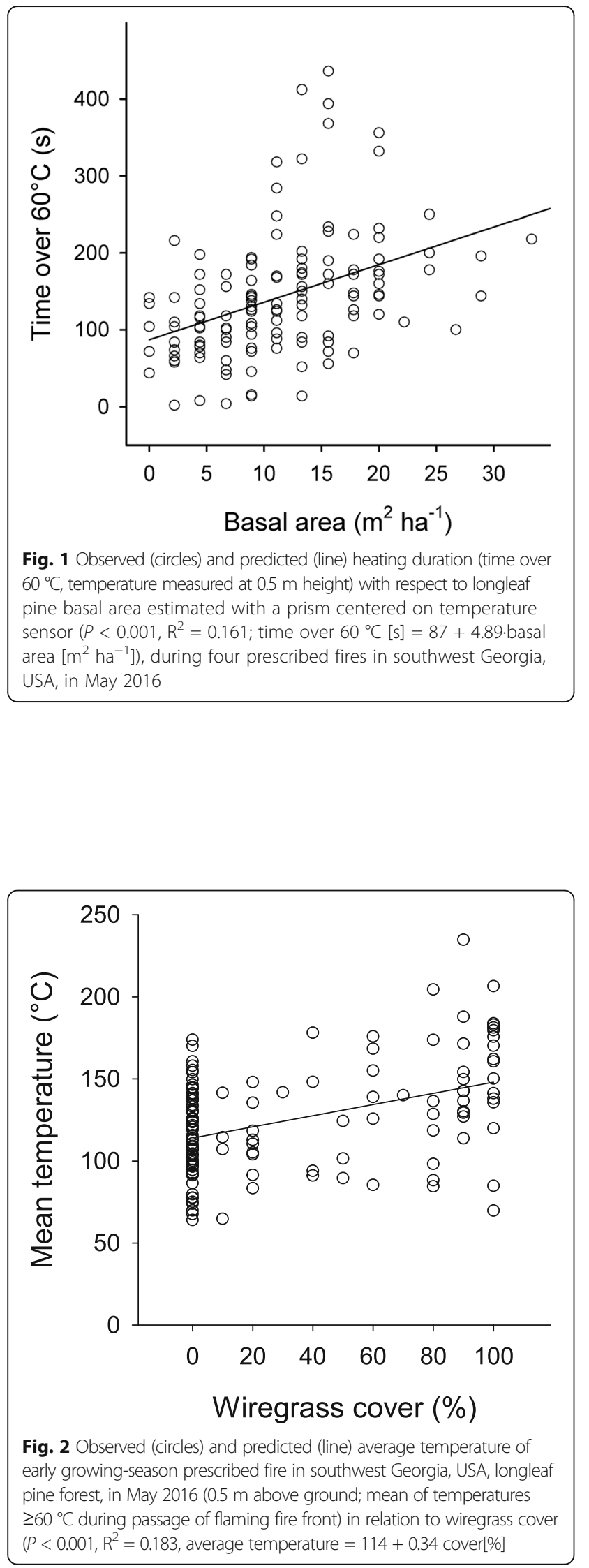

as height of herbaceous layer explained $\leq 3 \%$ of variation in mean air temperature.

\section{Neighborhood models of time over $60^{\circ} \mathrm{C}$}

The likelihood-based neighborhood analysis illustrated the relationship between time over $60{ }^{\circ} \mathrm{C}$ and proximity and size of surrounding longleaf pine trees. A negative exponential model expressing decline in time over $60^{\circ} \mathrm{C}$ with increasing distance from neighboring trees captured $29 \%$ of variation (Fig. 3). Adding wiregrass cover did not improve the model (Table 3), but incorporating wiregrass moisture (which varied from 0.022 to $0.135 \mathrm{~g} \mathrm{~g}^{-1}$ ) during fires captured an additional $4 \%$ of variation and caused an AICc difference of 5.77 (consistent with an evidence ratio of 17.9 (i.e., the negative exponential model incorporating wiregrass moisture is 17.9 times more likely to be the best model than the one without it). Parameters and support limits for the AICc-best model, which predicts time over $60{ }^{\circ} \mathrm{C}$ in s $100^{-1}$, are $Y_{\text {int }}=0.41(0.318,0.540) ; \lambda=4.97(4.19,5.83) ; \gamma=2.99$ (2.76, 3.34), and $w$ (multiplier for wiregrass moisture) $=$ $0.960(0.713,1.153)$. The effect of a longleaf pine on predicted time over $60{ }^{\circ} \mathrm{C}$ decreased by two thirds of its highest value (close to the trunk) at a distance of $3.3 \mathrm{~m}$ (i.e., $10 \gamma^{-1}$; Bolker 2008) from the tree.

\section{Post-fire tree survey}

The post-fire survey of small trees (0.5 to $5 \mathrm{~m}$ height) encountered mostly hardwoods but included some longleaf pine (Table 4). Average heights of all species were $\leq 2 \mathrm{~m}$ except for longleaf pine, which was $4.1 \mathrm{~m}$. Outright death after prescribed fire was extremely rare but top-kill was common: the proportion of individuals that were top-

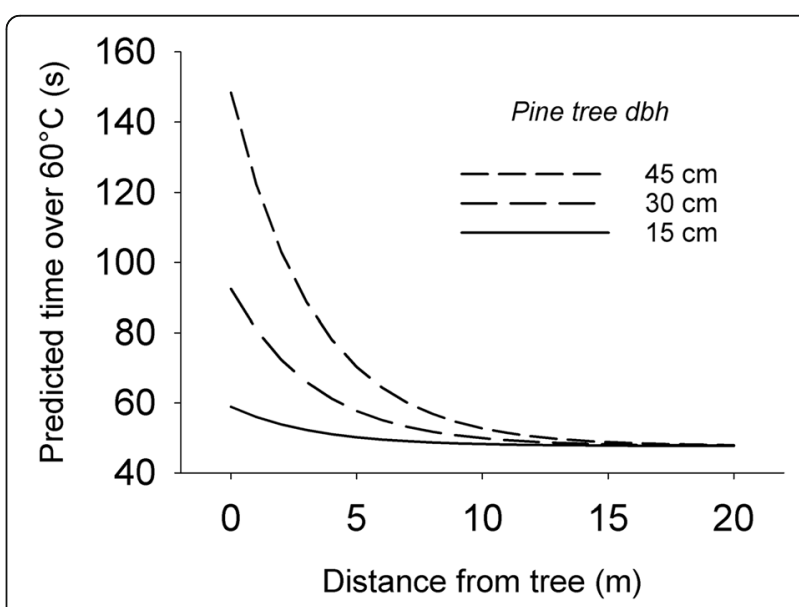

Fig. 3 Predicted heating duration (time over $60^{\circ} \mathrm{C}$ ) at varying distances from a single longleaf pine tree of 15,30 , and $45 \mathrm{~cm} \mathrm{dbh}$, based on a likelihood model in which wiregrass moisture during prescribed burns is fixed at a representative value of $0.07 \mathrm{~g} \mathrm{~g}^{-1}$, and whose parameters were derived from data on four prescribed burns in longleaf pine forest in southwest Georgia, USA, in May 2016 
Table 3 Model comparison for prediction of time over $60{ }^{\circ} \mathrm{C}$ during prescribed fires in longleaf pine forest in southwest Georgia, USA, during May 2016. Bold font indicates best model

\begin{tabular}{llllll}
\hline Model & $\mathrm{K}^{\mathrm{a}}$ & $\mathrm{L}$ & $\mathrm{R}^{2}$ & $\mathrm{AlCC}$ & $\Delta_{\mathrm{i}}$ \\
\hline Intercept-only (null) & 2 & -160.43 & 0.00 & 327.11 & 49.51 \\
$\mathrm{NE}^{\mathrm{b}}$ & 4 & -137.43 & 0.29 & 283.37 & 5.77 \\
$\mathrm{NE}+$ wiregrass & 5 & -136.39 & 0.30 & 283.82 & 6.22 \\
$\mathrm{NE}+$ wiregrass + NE · wiregrass & 6 & -137.13 & 0.29 & 286.92 & 9.32 \\
NE + wiregrass moisture & $\mathbf{5}$ & $-\mathbf{1 3 3 . 5 7}$ & $\mathbf{0 . 3 3}$ & $\mathbf{2 7 7 . 6 0}$ & $\mathbf{0 . 0 0}$
\end{tabular}

${ }^{a} \mathrm{~K}=$ number of parameters, $\mathrm{L}=$ log-likelihood, $\mathrm{R}^{2}=$ adjusted $\mathrm{R}^{2}, \mathrm{AIC}=$ samplesize-corrected Akaike's Information Criterion, and $\Delta_{\mathrm{i}}$ indicates strength of support from the data in comparison to the best model $\left(\Delta_{\mathrm{i}}<2=\right.$ substantial support, $4<$ $\Delta_{\mathrm{i}}<7=$ considerably less support, and $\Delta_{\mathrm{i}}>10=$ essentially no support; Burnham and Anderson 2002)

${ }^{\mathrm{b}} \mathrm{NE}$ is a neighborhood model based on dbh and distance of nearby longleaf pine trees

killed was $>60 \%$ for all species except longleaf pine, which does not experience top-kill as such. The proportion of top-killed individuals supported the a priori classification of hardwoods into guilds: proportion of top-kill of fleshy-fruited trees and mesic oaks was $\geq 90 \%$, proportion of top-kill of upland oaks was 85 to $86 \%$, and proportion of top-kill of xeric oaks was 62 to $63 \%$.

\section{Neighborhood models of top-kill}

Of the two top-kill probability functions, the logistic performed worse than the Michaelis-Menten function under all except the simplest model formulation and will not be considered further (Table 5). Neighborhood density of canopy trees influenced top-kill by increasing top-kill at greater NDI $\left(\Delta_{\mathrm{i}}=493.80\right)$, but the influence of height of target hardwood tree was even stronger $\left(\Delta_{\mathrm{i}}=294.01\right.$; lower probability of top-kill with taller hardwoods). A combination of NDI and hardwood height as predictor variables in the Michaelis-Menten function produced a still better model $\left(\Delta_{i}=145.28\right)$, and estimating a different height coefficient for each hardwood guild led to the best model $\left(\Delta_{i}=0\right)$. Estimating a different set of asymptote and slope parameters for each hardwood guild led to a small increase in likelihood, which was cancelled out by the penalty associated with the increase in number of parameters $\left(\Delta_{\mathrm{i}}=6.09\right)$.

The component of the neighborhood equation that weights canopy tree diameter by distance had an exponent of $\gamma=2.10( \pm 2$ AIC unit support interval 2.00 to 2.19; Equation 1) in the best model, indicating that the influence of a pine tree on top-kill decreased by two thirds at a distance of $4.8 \mathrm{~m}$ from the base of the pine. The asymptote parameter of the Michaelis-Menten equation was 1 ( 1 to 1 ), and the slope parameter was 563 (490 to 668). The negative exponent $c$ in the power function of hardwood height expressed differences among hardwood guilds. Parameter values and support intervals for fleshy-fruited trees and mesic oaks were respectively 2.16 (1.77 to 2.44 ) and 2.44 (1.93 to 2.89 ), suggesting that top-kill susceptibility in these guilds decreases with the inverse square of hardwood height (Fig. 4). The broad overlap in support intervals indicates close similarity between fleshy-fruited trees and mesic oaks. The $c$ parameter was much greater for upland and xeric oaks, 4.14 (3.67 to 4.83 ) and 5.10 (4.64 to 5.45 ), respectively, indicating that top-kill susceptibility decreased with the inverse of height to the fourth or fifth power for these guilds. Support intervals overlapped for

Table 4 Condition of hardwood trees and longleaf pine (0.5 to $5 \mathrm{~m}$ height) after prescribed burns in an upland longleaf pine forest in southwest Georgia, USA, in May 2016: sample included silvicultural openings up to 0.4 ha. Guilds include ff = fleshy-fruited hardwoods, $\mathrm{mo}=$ mesic oaks, $\mathrm{uo}=$ upland oak, $\mathrm{xo}=$ xeric oak, $\mathrm{c}=$ conifer. Post-fire conditions include T/K = top-kill (fully scorched, with basal resprouting); $\mathrm{D}=$ dead (fully scorched, no resprouting); $C / R=$ crown resprouting (fully scorched with crown resprouting); $\mathrm{U} / \mathrm{S}=$ unscorched (burned but with part of crown remaining green)

\begin{tabular}{|c|c|c|c|c|c|c|c|c|c|}
\hline \multirow[b]{2}{*}{ Species } & \multirow[b]{2}{*}{ Guild } & \multicolumn{2}{|c|}{ Density $\left(\mathrm{ha}^{-1}\right)$} & \multicolumn{2}{|c|}{ Height (m) } & \multicolumn{4}{|c|}{ Post-fire condition (\%) } \\
\hline & & Stem & Genet & Stem & Scorch & $\mathrm{T} / \mathrm{K}$ & $\mathrm{D}$ & $\mathrm{C} / \mathrm{R}$ & $\mathrm{U} / \mathrm{S}$ \\
\hline Persimmon & $\mathrm{ff}$ & 424 & 303 & 1.3 & 1.2 & 92 & 0 & 4 & 3 \\
\hline Sassafras & $\mathrm{ff}$ & 1569 & 966 & 1.6 & 1.5 & 94 & 0 & 1 & 4 \\
\hline Black cherry & ff & 210 & 78 & 2.0 & 1.7 & 94 & 0 & 0 & 6 \\
\hline Water oak & mo & 800 & 339 & 1.7 & 1.5 & 92 & 1 & 3 & 3 \\
\hline Laurel oak & mo & 281 & 145 & 2.0 & 1.5 & 94 & 0 & 2 & 5 \\
\hline Live oak & mo & 407 & 214 & 1.6 & 1.3 & 93 & 0 & 2 & 5 \\
\hline Post oak & no & 27 & 23 & 1.2 & 1.2 & 85 & 0 & 15 & 0 \\
\hline South. red oak & uo & 979 & 280 & 1.6 & 1.5 & 86 & 0 & 9 & 5 \\
\hline Bluejack oak & xo & 546 & 313 & 2.0 & 1.7 & 63 & 0 & 14 & 23 \\
\hline Sand post oak & xo & 115 & 98 & 1.8 & 1.6 & 62 & 0 & 17 & 21 \\
\hline Longleaf pine & c & 178 & 178 & 4.1 & 2.6 & 0 & 6 & 26 & 68 \\
\hline
\end{tabular}


Table 5 Comparison of models of hardwood top-kill probability after prescribed burns in upland longleaf pine forest in southwest Georgia, USA, in May 2016. Models express hardwood top-kill probability as Michaelis-Menten (MM) or logistic (LG) functions of density of neighboring pine trees (neighborhood density index: NDI), hardwood height $(\mathrm{Ht})$, or both. Hardwood species are treated as a group or separated by guild (denoted by subscripted g) representing fleshy-fruited trees, mesic oaks, upland oaks, and xeric oaks. Bold font shows the best model (i.e., with lowest AICc), in which differences among hardwood guilds are expressed by an exponent that modifies height

\begin{tabular}{|c|c|c|c|c|c|}
\hline Model & $K^{a}$ & $\mathrm{~L}$ & $\mathrm{R}^{2}$ & $\mathrm{AlCc}$ & $\Delta_{\mathrm{i}}$ \\
\hline Intercept-only & 1 & -1049.68 & 0.00 & 2101.36 & 865.69 \\
\hline$M M=f(N D I)$ & 3 & -861.73 & 0.23 & 1729.47 & 493.80 \\
\hline$L G=f(N D I)$ & 3 & -816.15 & 0.28 & 1638.32 & 402.69 \\
\hline$M M=f(H t)$ & 3 & -761.84 & 0.34 & 1529.68 & 294.01 \\
\hline$L G=f(H t)$ & 3 & -771.29 & 0.33 & 1548.60 & 312.93 \\
\hline$M M=f(N D I, H t)$ & 4 & -686.47 & 0.43 & 1380.95 & 145.28 \\
\hline $\mathrm{LG}=\mathrm{f}(\mathrm{NDI}, \mathrm{Ht})$ & 4 & -695.94 & 0.42 & 1399.89 & 164.22 \\
\hline$M M=f\left(N D I, H_{g}\right)$ & 7 & -610.82 & 0.50 & 1235.67 & 0.00 \\
\hline $\mathrm{LG}=\mathrm{f}\left(\mathrm{NDI}, \mathrm{Ht}_{\mathrm{g}}\right)$ & 7 & -646.46 & 0.47 & 1306.95 & 71.28 \\
\hline $\mathrm{MM}_{\mathrm{g}}=\mathrm{f}\left(\mathrm{NDI}, \mathrm{Ht}_{\mathrm{g}}\right)$ & 13 & -607.82 & 0.50 & 1241.76 & 6.09 \\
\hline $\mathrm{LG}_{\mathrm{g}}=\mathrm{f}\left(\mathrm{NDI}, \mathrm{Ht}_{\mathrm{g}}\right)$ & 13 & -621.07 & 0.49 & 1268.27 & J2. \\
\hline
\end{tabular}

${ }^{a} K=$ number of parameters, $L=$ log-likelihood, $R^{2}=$ Nagelkerke's $R^{2}$ for discrete models, AICc = sample-size-corrected Akaike's Information Criterion, and $\Delta_{\mathrm{i}}$ indicates strength of support from the data in comparison to the best model $\left(\Delta_{\mathrm{i}}<2=\right.$ substantial support, $4<\Delta_{\mathrm{i}}<7=$ considerably less support, and $\Delta_{\mathrm{i}}>10=$ essentially no support; Burnham and Anderson 2002) these guilds and were distinct from those of the fleshy-fruited trees and mesic oaks.

\section{Discussion}

Individual longleaf pine trees produced a clearly detectable pattern of influence on prescribed fire air temperature and hardwood top-kill. The result emphasizes the idea that individual trees impose structure on understory processes, knitting forest stands together in overlapping circles of influence. Use of neighborhoodbased likelihood methods to define these circles of influence is well established for processes such as seed dispersal (Ribbens et al. 1994), leaf dispersal (Bigelow and Canham 2015), and inter-tree competition (Canham et al. 2006), but the present application in a fire-based context is novel. The principles behind the influence of individual pine trees on fire behavior and effects have long been known (Williamson and Black 1981; Boyer 1990), but here we present spatially accurate models. The ability to predict effect of individual trees on key processes, in a spatially explicit framework, suggests the possibility of predicting effects of novel silvicultural treatments on these processes.

Application of the neighborhood models in this paper may be limited by low explanatory power, and at least four unmeasured factors may have exerted substantial influence on time over $60{ }^{\circ} \mathrm{C}$. First, cover and moisture content of herbaceous species other than wiregrass were not accounted for, and these may influence prescribed fire behavior (Kirkman and Giencke 2017). Second,

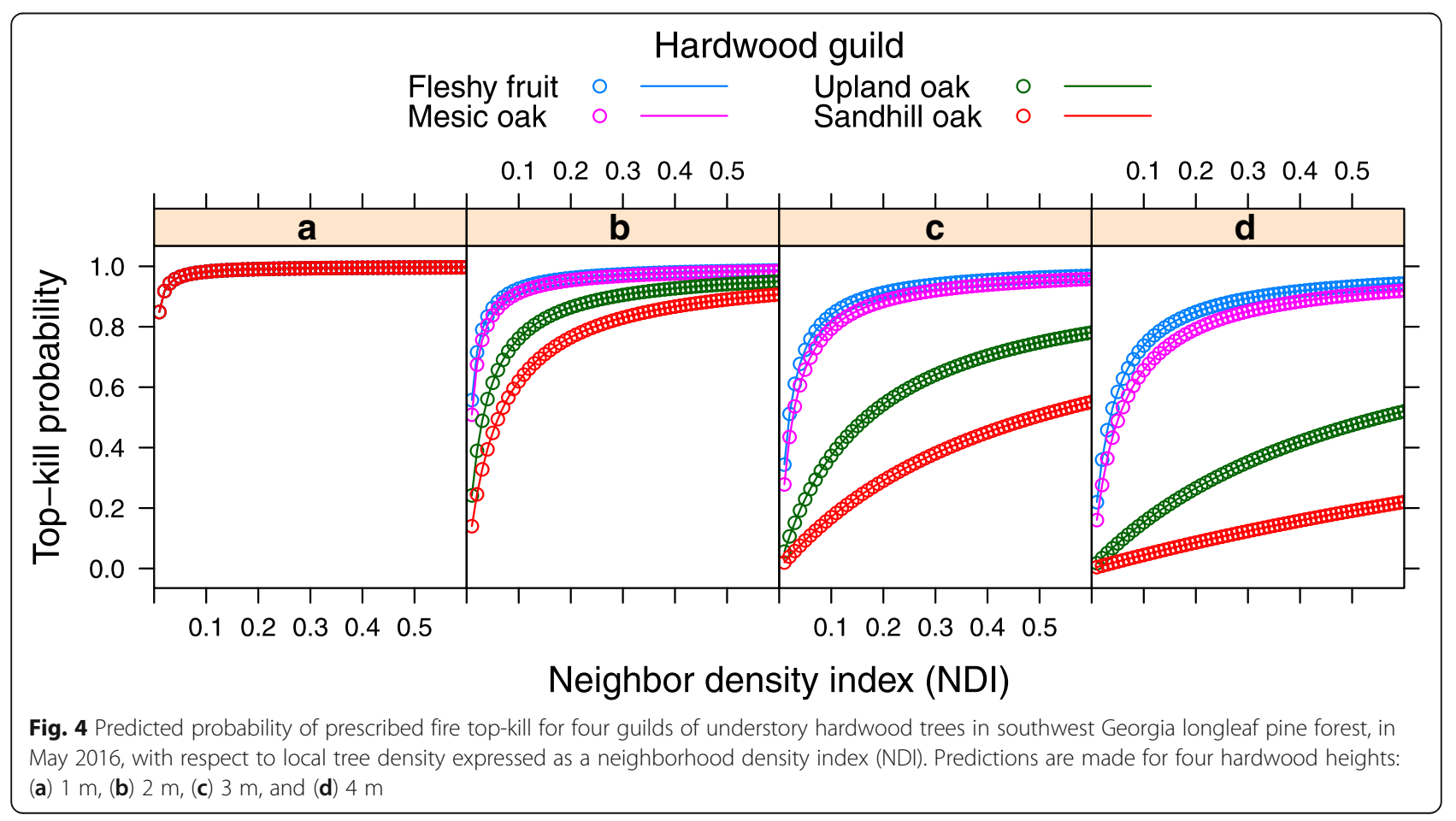


downed wood and cones near thermocouples were not measured and these may have influenced residence time (O'Brien et al. 2016). Third, litter from the small numbers of hardwoods in the overstory would have different burning properties than longleaf pine (Varner et al. 2016). Fourth, we did not measure moisture content of longleaf litter, which has a somewhat longer equilibrium time-lag than wiregrass (Nelson and Hiers 2008). Establishing the contribution of these factors to time over 60 ${ }^{\circ} \mathrm{C}$ will improve precision of predictions.

Notwithstanding the importance of hardwood regulation in longleaf pine forest management, isolated or small clumps of mature hardwoods play important roles in the ecosystem, particularly for wildlife (Hiers et al. 2013). Oaks provide hard mast for many wildlife species, and isolated hardwoods within an open-pine matrix constitute high-quality habitat for Sherman's fox squirrel (Sciurus niger shermani Moore), an iconic species of the southern pinelands (Prince et al. 2016). Hardwoods, particularly mesic oaks, develop cavities that are utilized by bats and snakes (Howze et al. 2019). Small clumps of hardwoods may have value as thermal or fire-free refuges for organisms of limited mobility (Neel and McBrayer 2018; Roe et al. 2019). The ecological value of individual or small groups of hardwoods in a longleaf pine matrix, as opposed to the deleterious effect of mass hardwood recruitment from fire exclusion, implies the need for information on selective control of hardwoods using prescribed fire.

\section{Influences on fire temperature and duration}

Air temperature during prescribed fire is influenced by fire convective energy release; for example, maximum air temperature was correlated with fire convective energy and total energy release of prescribed fires in longleaf pine forest on a sandhill site $(P=0.01$ and $P=$ 0.027, respectively; analysis of data in Butler et al. 2016). Our measurements were done at a lower frequency and with thermocouple beads that are slightly larger than optimal for capturing the dynamics of the flames, buoyant plume, and smoldering combustion that influence prescribed fire air temperature (Bova 2008). Nevertheless, the relatively long residence times $(>2$ min average) and use of mean instead of maximum temperature would have minimized artifact stemming from these issues in our experiment. Overall, our system provided a flexible compromise between measurement precision and the need to take widely dispersed measurements with equipment rugged enough to withstand fire.

The strong spatial imprint of individual longleaf pine trees on fire duration was striking. Mean fire duration increased by $5 \mathrm{~s}$ for every $1 \mathrm{~m}^{2} \mathrm{ha}^{-1}\left(4.4\right.$ feet $^{2}$ acre $\left.^{-1}\right)$ increase in local basal area (Fig. 1). The effect of an individual tree on fire duration was strongest closest to its trunk, decreasing to one third of maximum at $3.3 \mathrm{~m}=$ $10 \gamma^{-1}$ (Bolker 2008). We infer that a tree's effect on pattern of time over $60{ }^{\circ} \mathrm{C}$ is due to needle fall (O'Brien et al. 2008), because pine needles have higher energy content than other fuels like broadleaved litter or litter from fine dead surface fuels (Reid and Robertson 2012). The lack of longleaf pine effect on mean air temperature is consistent with previous research in which needle fuels were manipulated (Jack et al. 2007). Fill et al. (2016) found that pine needles and other litter fuels perched on wiregrass tussocks increase duration of flaming and smoldering but not flame length (a reflection of fireline intensity). Pine cones, which release intense heat when burned, are also components of longleaf pine canopy-derived litter and likely contributed to the spatial pattern noted (O'Brien et al. 2016). Predicted time over $60{ }^{\circ} \mathrm{C}$ at a given point in the forest will depend on distance to, size of, and number of surrounding trees.

It is axiomatic for prescribed fire practitioners in Southeastern USA that a longleaf pine overstory with wiregrass ground cover is a prized fuel bed, because ignition can be achieved under damp or cool weather conditions that otherwise may impede burning (Kirkman and Giencke 2017: 213, M. Melvin, personal communication). By the same token, this combination of fuels can produce intense fires, so managers must use caution under dry conditions. Wiregrass's burning characteristics are related to the low bulk density and even foliage distribution of the clumps, and to the high surface area-to-volume ratio of individual leaf blades (Fill et al. 2016). Our finding that predicted mean air temperature increased by $3.4{ }^{\circ} \mathrm{C}$ per $10 \%$ increase in wiregrass cover was consistent with these observations (Fig. 2), confirming the importance of wiregrass as the preeminent ground cover fuel of longleaf pine forest. Nevertheless, our data did not support the idea that the flammability of wiregrass and longleaf pine needles together differs from what would be expected based on their behavior in isolation (i.e., that there is a non-additive, synergistic effect; Hendricks et al. 2002; van Altena et al. 2012). The presence of wiregrass did not significantly increase time over $60{ }^{\circ} \mathrm{C}$. Rather than constituting a true synergism (interaction in which the total effect is greater than the sum of individual effects), the effectiveness of the combination of longleaf pine and wiregrass fuels may stem from their influence on different components of fire behavior (i.e., duration of flaming versus high temperatures).

\section{Hardwood shrub top-kill}

Preventing hardwoods from growing large enough to shade out a diverse ground cover is an important motivation for the application of prescribed fire in open pine woodlands. The impact of longleaf pine on hardwood top-kill from prescribed fire was quantified by Rebertus 
et al. (1989), who determined that turkey oak's crown survival was positively related to its size (dbh) and distance to the nearest large longleaf pine, and was inversely related to the size of the pine. Our study confirmed and extended this result. Incorporating the neighborhood density index NDI made it possible to compare the scale at which an individual pine tree's influence is exerted on fire behavior and hardwood top-kill. This scale is similar for fire (time over $60{ }^{\circ} \mathrm{C}$ ) and top-kill, indicating similar spatial scale of operation of these processes and implicating time over $60{ }^{\circ} \mathrm{C}$ in hardwood top-kill (O’Brien et al. 2016).

Hardwood stem height has been linked to vulnerability to surface fires in open forest-grassland systems (Lawes et al. 2011; Werner and Prior 2013), and hardwood top-kill in our study was strongly height dependent. Such height dependence is related not only to elevation of the crown above the heat of prescribed fire but also to bark thickness. Bark development is allometrically related to height, and so taller trees will have thicker bark at the stem bases, which protects vascular cambium by insulating from heat (Dickinson and Johnson 2004; Graves et al. 2014; Varner et al. 2016). The southern hardwood guilds are clearly differentiated in bark thickness, especially when individuals are small (e.g., $<1 \mathrm{~m}$ height); the species composing the xeric and upland oak guilds have thick bark (e.g., $>1 \mathrm{~cm}$ for the outer bark), and the species composing the mesic oak and fleshy-fruited guilds have substantially thinner bark (e.g., $<0.85 \mathrm{~cm}$; Jackson et al. 1999; Romero et al. 2009). Our findings on differences in fire mortality among guilds were consistent with these classifications.

Neighborhood density and hardwood height interacted in their effect on hardwood guild top-kill. Neighborhood density had little impact when hardwoods were $<1 \mathrm{~m}$ tall, and predicted top-kill was close to $100 \%$ for all guilds. The effect of neighborhood density became much more evident for taller target trees. At $2 \mathrm{~m}$ height, top-kill of mesic oaks and fleshy-fruited trees was clearly differentiated from that of upland oaks and mesic oaks. For example, at an NDI of 0.1 (equivalent to $3 \mathrm{~m}$ distance from a $45 \mathrm{~cm}$ dbh longleaf pine), top-kill probability of mesic oaks and fleshy-fruited trees was $97 \%$, compared to $88 \%$ for upland oaks and xeric oaks. This finding is consistent with that of Whelan et al. (2018), who also found that top-kill probability of these groups becomes clearly differentiated when hardwood height is $>1.5 \mathrm{~m}$. It appears that, when hardwoods are small ( 1 $\mathrm{m}$ height), fire from surface fuels alone is enough to top-kill them, and the fuel from pine trees is in excess of the requirement for effective top-kill. When hardwoods are larger and more fire tolerant, it takes the additional heating duration provided by fine needle fuels to top-kill them. At greater heights, the hardwoods become highly resistant to top-kill, scaling with the magnitude of the $c$ exponent. Once xeric oaks are $2 \mathrm{~m}$ in height, they have become extremely resilient to fire. Although evergreen oaks may grow more rapidly in height than the deciduous oaks (Whelan et al. 2018), the rapid height growth may not be enough to compensate for the thin bark and high top-kill probability.

\section{Implications for silviculture and gap size}

Forest managers require a range of silvicultural options to meet multiple objectives of managing natural longleaf pine forest (Brockway and Outcalt 2017). Single-tree selection under the Stoddard-Neel system is a well established system for longleaf pine forest harvest (Mitchell et al. 2006), and when applied properly, results in somewhat even spacing of residual longleaf pine trees that provides continuous coverage of needle fuels (Jack and McIntyre 2017). The effectiveness of hardwood control is not only due to top-kill from prescribed fire but likely also due to growth suppression of hardwoods by competition from overstory trees (Pecot et al. 2007). When density is high enough that spatial-influence circles of neighboring trees coalesce, effective control can be maintained even at high understory hardwood density, which frequently reaches $>1000 \mathrm{ha}^{-1}$ (Provencher et al. 2001; Outcalt and Brockway 2010; Whelan et al. 2018).

Management objectives may dictate canopy openings larger than those left by single-tree selection; for example, large canopy openings could improve establishment of longleaf pine seedlings due to lower fire severity, or increase recruitment of longleaf pine saplings to the canopy (Brockway and Outcalt 1998; Mitchell et al. 2006). Such openings inevitably diminish control over hardwoods in the understory, as when creation of group selection openings resulted in greatly increased hardwood dominance less than a decade after cutting treatments (Jack et al. 2006). Hardwood dominance is likely related to reduced top-kill due to decreased litter input, as well as increased growth rate due to reduced belowground competition from pines (Jack et al. 2007; Pecot et al. 2007). Guidelines about maximum feasible gap size in longleaf pine forest are usually based on longleaf pine regeneration, (e.g., regeneration may be maximized in gaps as small as 0.1 ha [McGuire et al. 2001], or regeneration will be poor in gaps $<15 \mathrm{~m}$ radius $[0.07 \mathrm{ha}$; Brockway and Outcalt 1998]). Modifications to group selection systems, such as retention of reserve trees within openings, may enhance control of hardwoods while maintaining some of the benefits of larger openings (Franklin et al. 1997), and these effects of such modifications can be simulated with neighborhood methods.

The top-kill model and associated parameters provide a way to predict gap size effect on top-kill probability of hardwoods of specified size, with the caveat that the top-kill model is phenomenological: its parameters were estimated based on prescribed fires done under a limited range of environmental conditions (Table 1), in longleaf 
pine forests managed on a two-year burn interval. The applicability of the model parameters under different circumstances, such as a longer burn interval, would be influenced by altered fuel beds, which might have more pine and hardwood litter and less ground cover. Differing fuel beds would unavoidably influence accuracy of top-kill predictions (Ellair and Platt 2013). Additionally, the presence of wiregrass ground cover, although not found to affect time over $60{ }^{\circ} \mathrm{C}$ in our study, has been observed to influence prescribed fire effectiveness and may modify effectiveness of hardwood control at a given opening size (Fill et al. 2017). Our findings provide some guidance on the effect of gap size and prescribed fire and hardwood performance. Future studies should simultaneously address hardwood mortality and survival of longleaf pine regeneration, under varying fire conditions.

\section{Conclusions}

Control of understory hardwoods is a perennial issue for silvicultural systems of open-canopy longleaf pine forest managed with frequent fire. We have shown that influence of individual longleaf pines on fire environment and hardwood mortality, beneath and close to their crown, is predictable from simple mathematical relationships. These relationships open the door to using spatially explicit neighborhood models to predict effects of novel cutting and planting patterns on fire and hardwood performance. It is also true that ground cover such as wiregrass interacts with overstory influences to determine fire behavior and effects, and this interaction can modify conclusions regarding gap sizes that may maintain hardwood top-kill at acceptable levels. Further investigation of how overstory-derived surface fuels interact with ground cover to influence heat flux and top-kill is warranted. Ultimately, novel cutting and planting patterns are worth pursuing because, as the longleaf pine restoration movement proceeds, and plantations are converted into more natural configurations, we need systems for management that balance a range of objectives-regeneration, fuels for fire, control of hardwoods, and habitat structure for wildlife.

\section{Acknowledgements}

We are grateful for many insights provided by J. Atkinson and M. Melvin. We thank A. Cuminale, N.A. Jansen, and M.F. Nieminen for field work; J. Brock for GIS assistance; R.J. Mitchell (deceased) for initiating the selection-system study and S.B. Jack for maintaining it; D. Aubrey and S.B. Jack for reviewing the manuscript; and two reviewers and an associate editor for careful reviews that contributed to manuscript improvements.

\section{Funding}

This study was funded by the Robert W. Woodruff Foundation

\section{Availability of data and materials}

The datasets and computer code supporting the conclusions of this article will be available in the Dryad repository (http://www.datadryad.org).
Authors' contributions

SWB conceived the study, analyzed the data, and wrote the manuscript. AWW carried out the study. Both authors read and approved the final manuscript.

Ethics approval and consent to participate

Not applicable

\section{Consent for publication}

Not applicable

\section{Competing interests}

The authors declare that they have no competing interests.

\section{Publisher's Note}

Springer Nature remains neutral with regard to jurisdictional claims in published maps and institutional affiliations.

Received: 15 October 2018 Accepted: 7 May 2019

Published online: 05 August 2019

\section{References}

Bigelow, S.W., and C.D. Canham. 2015. Litterfall as a niche construction process in a northern hardwood forest. Ecosphere 6: Art117 https://doi.org/10.1890/ ES14-00442.1.

Bigelow, S.W., and C.D. Canham. 2017. Neighborhood-scale analyses of nonadditive species effects on cation concentrations in forest soils. Ecosystems 20: 1351-1363 https://doi.org/10.1007/s10021-017-0116-1.

Bigelow, S.W., N.A. Jansen, S.B. Jack, and C.L. Staudhammer. 2018. Influence of selection method on skidder-trail soil compaction in longleaf pine forest. Forest Science 64: 641-652 https://doi.org/10.1093/forsci/fxy023.

Bolker, B. 2008. Ecological models and data in R. Princeton: Princeton University Press https://doi.org/10.2307/j.ctvcm4g37.

Bond, W.J., and J.J. Midgley. 2000. Ecology of sprouting in woody plants: the persistence niche. Trends in Ecology \& Evolution 16: 45-51 https://doi.org/10. 1016/50169-5347(00)02033-4.

Boring, L.R., J.J. Hendricks, R.S. Taylor, and D. Markewitz. 2017. Ecosystem processes and restoration. In Ecological restoration and management of longleaf pine forests, ed. L.K. Kirkman and S.B. Jack, 123-139. Boca Raton: CRC Press.

Bova, A. S., and M. B. Dickinson. 2008. Beyond "fire temperatures": calibrating thermocouple probes and modeling their response to surface fires in hardwood fuels. Canadian Journal of Forest Research 38: 1008-1020 https:// doi.org/10.1139/X07-204.

Boyer, W.D. 1990. Growing-season burns for control of hardwoods in longleaf pine stands. USDA Forest Service Research Paper RP-SO-256. New Orleans: USDA Forest Service Southern Forest Experiment station. https://doi.org/ 10.2737/SO-RP-256.

Brockway, D.G., and K.W. Outcalt. 1998. Gap-phase regeneration in longleaf pine wiregrass ecosystems. Forest Ecology and Management 106: 125-139 https:// doi.org/10.1016/S0378-1127(97)00308-3.

Brockway, D.G., and K.W. Outcalt. 2017. Influence of reproduction cutting methods on structure, growth and regeneration of longleaf pine forests in flatwoods and uplands. Forest Ecology and Management 389: 249-259 https://doi.org/10.1016/j.foreco.2017.01.002.

Burnham, K.P., and D.R. Anderson. 2002. Model selection and multimodel inference. 2nd ed. New York: Springer.

Butler, B., C. Teske, D. M. Jimenez, J. O'Brien, P. Sopko, C. Wold, M. Vosburgh, B. Hornsby, and E. Loudermilk. 2016. Observations of energy transport and rate of spreads from low-intensity fires in longleaf pine habitat: RXCADRE 2012. International Journal of Wildland Fire 25: 76-89 https://doi.org/10.1071/ WF14154.

Canham, C., and M. Uriarte. 2006. Analysis of neighborhood dynamics of forest ecosystems using likelihood methods and modeling. Ecological Applications 16: 62-73 https://doi.org/10.1890/04-0657.

Canham, C.D., M.J. Papaik, M. Uriarte, W.H. McWilliams, J.C. Jenkins, and M.J. Twery. 2006. Neighborhood analyses of canopy tree competition along environmental gradients in New England forests. Ecological Applications 16: 540-554 https://doi.org/10.1890/1051-0761 (2006)016[0540:NAOCTC]2.0.CO;2. 
Cavender-Bares, J., K. Kitajima, and F.A. Bazzaz. 2004. Multiple trait associations in relation to habitat differentiation among 17 Floridian oak species. Ecological Monographs 74: 635-662 https://doi.org/10.1890/03-4007.

Dell, J.E., L.A. Richards, J.J. O'Brien, E.L. Loudermilk, A.T. Hudak, S.M. Pokswinski, B. C. Bright, J.K. Hiers, B.W. Williams, and L.A. Dyer. 2017. Overstory-derived surface fuels mediate plant species diversity in frequently burned longleaf pine forests. Ecosphere 8: Article e01964. https://doi.org/10.1002/ecs2.1964.

Dickinson, M.B., and E.A. Johnson. 2001. Fire effects on trees. Chapter 14. In Forest fires: behavior and ecological effects, ed. E.A. Johnson and K. Miyanishi, 477-525. San Diego: Academic https:/doi.org/10.1016/B978-012386660-8/50016-7.

Dickinson, M.B., and E.A. Johnson. 2004. Temperature-dependent rate models of vascular cambium cell mortality. Canadian Journal of Forest Research 34: 546 559 https://doi.org/10.1139/x03-223.

Ellair, D.P., and W.J. Platt. 2013. Fuel composition influences fire characteristics and understorey hardwoods in pine savanna. Journal of Ecology 101: 192$201 \mathrm{https}: / /$ doi.org/10.1111/1365-2745.12008.

Ferrari, J.B., and S. Sugita. 1996. A spatially explicit model of leaf litter fall in hemlock-hardwood forests. Canadian Journal of Forest Research 26: 1905-1913 https://doi.org/10.1139/×26-215.

Fill, J.M., J.S. Glitzenstein, D.R. Streng, J. Stowe, and T.A. Mousseau. 2017. Wiregrass (Aristida beyrichiana) may limit woody plant encroachment in longleaf pine (Pinus palustris) ecosystems. The American Midland Naturalist 177: 153-161 https://doi.org/10.1674/0003-0031-177.1.153.

Fill, J.M., B.M. Moule, J.M. Varner, and T.A. Mousseau. 2016. Flammability of the keystone savanna bunchgrass Aristida stricta. Plant Ecology 217: 331-342 https://doi.org/10.1007/s11258-016-0574-0.

Franklin, J.F., D.R. Berg, D.A. Thornburgh, and J.C. Tappeiner. 1997. Alternative silvicultural approaches to timber harvesting: variable retention harvest systems. In Creating a forestry for the $21^{\text {st }}$ century, ed. K.A. Kohm and J.F. Franklin, 111-138. Washington, D.C.: Island Press.

Franklin, J.F., R.J. Mitchell, and B.J. Palik. 2007. Natural disturbance and stand development principles for ecological forestry. USDA Forest Service General Technical Report NRS-GTR-19. Newtown Square: USDA Forest Service, Northern Research Station. https://doi.org/10.2737/NRS-GTR-19.

Grady, J.M., and W.A. Hoffman. 2012. Caught in a fire trap: recurring fire creates stable size equilibria in woody resprouters. Ecology 93: 2052-2060 https://doi. org/10.1890/12-0354.1.

Graves, S.J., S.W. Rifai, and F.E. Putz. 2014. Outer bark thickness decreases more with height on stems of fire-resistant than fire-sensitive Floridian oaks (Quercus spp.; Fagaceae). American Journal of Botany 101: 2183-2188 https:// doi.org/10.3732/ajb.1400412.

Grömping, U. 2006. Relative importance for linear regression in R: the package relaimpo. Journal of Statistical Software 17 (1): 1-27 https://doi.org/10.18637/ jss.v017.i01.

Hendricks, J.., C.A. Wilson, and L.R. Boring. 2002. Foliar litter position and decomposition in a fire-maintained longleaf pine-wiregrass ecosystem. Canadian Journal of Forest Research 32: 928-941 https://doi.org/10.1139/x02-020.

Hiers, J.K., J.R. Walters, R.J. Mitchell, J.M. Varner, L.M. Conner, L.A. Blanc, and J. Stowe. 2013. Ecological value of retaining pyrophytic oaks in longleaf pine ecosystems. Journal of Wildlife Management 78: 383-393 https://doi.org/10. 1002/jwmg.676.

Holland, A.M., B.T. Rutledge, S.B. Jack, and J.M. Stober. 2019. The longleaf pine forest: long-term monitoring and restoration of a management dependent ecosystem. Journal for Nature Conservation 47: 38-50 https://doi.org/10.1016/ j.jnc.2018.11.006.

Howze, J.M., K.J. Sash, J.P. Carroll, and L.L. Smith. 2019. A regional scale assessment of habitat selection and home range of the eastern rat snake in pine-dominated forests. Forest Ecology and Management 432: 225-230 https://doi.org/10.1016/j.foreco.2018.09.018.

Jack, S.B., J.K. Hiers, R.J. Mitchell, and J.L. Gagnon. 2007. Fuel loading and fire intensity: effects on longleaf pine seedling survival. In Proceedings of the $14^{\text {th }}$ biennial Southern silvicultural research conference. USDA Forest Service General Technical Report GTR-SRS-121, ed. J.A. Stanturf, 275-279. Asheville: USDA Forest Service, Southern Research Station.

Jack, S.B., and R.K. McIntyre. 2017. Restoring and managing the overstory: an ecological forestry approach. In Ecological restoration of the longleaf pine forest, ed. L.K. Kirkman and S.B. Jack, 175-204. Boca Raton: CRC Press.

Jack, S.B., R.J. Mitchell, and S.D. Pecot. 2006. Silvicultural alternatives in a longleaf pine/wiregrass woodland in southwest Georgia: understory hardwood response to harvest-created gaps. In Proceedings of the $13^{\text {th }}$ biennial Southern silvicultural research conference. USDA Forest Service General Technical Report GTR-SRS-92, ed. K.F. Connor. Pages 85-89. Asheville: USDA Forest Service, Southern Research Station.

Jackson, J.F., D.C. Adams, and U.B. Jackson. 1999. Allometry of constitutive defense: a model and a comparative test with tree bark and fire regime. American Naturalist 153: 614-632 https://doi.org/10.1086/303201.

Kennard, D.K., and K.W. Outcalt. 2006. Modeling spatial patterns of fuels and fire behavior in a longleaf pine forest in the southeastern USA. Fire Ecology 2: 31-52.

Kirkman, L.K., and L.M. Giencke. 2017. Restoring and managing a diverse ground cover. In Ecological restoration and management of longleaf pine forests, ed. L.K. Kirkman and S.B. Jack. Boca Raton. 207-232. CRC Press.

Kirkman, L.K., L.M. Giencke, R.S. Taylor, L.R. Boring, C.L. Staudhammer, and R.J. Mitchell. 2016. Productivity and species richness in longleaf pine woodlands: resource-disturbance influences across an edaphic gradient. Ecology 97: 2259-2271 https://doi.org/10.1002/ecy.1456.

Lawes, M.J., H. Adie, J. Russell-Smith, B. Murphy, and J.J. Midgley. 2011. How do small savanna trees avoid stem mortality by fire? The roles of stem diameter, height and bark thickness. Ecosphere 2: Article 42 https://doi.org/10.1890/ ES10-00204.1.

Loudermilk, E.L., J.J. O'Brien, R.J. Mitchell, W.P. Cropper Jr., J.K. Hiers, S. Grunwald, J. Grego, and J.C. Fernandez-Diaz. 2012. Linking complex forest fuel structure and fire behaviour at fine scales. International Journal of Wildland Fire 21: 882-893 https://doi.org/10.1071/WF10116.

MacFarlane, D., and R.K. Kobe. 2006. Selecting models for capturing tree-size effects on growth-resource relationships. Canadian Journal of Forest Research 36: 1695-1704 https://doi.org/10.1139/X06-054.

McGuire, J.P., R.J. Mitchell, E.B. Moser, S.D. Pecot, D.H. Gjerstad, and C.W. Hedman. 2001. Gaps in a gappy forest: plant resources, longleaf pine regeneration, and understory response to tree removal in longleaf pine savannas. Canadian Journal of Forest Research 31: 765-778. https://doi.org/10.1139/x01003 https://doi.org/10.1139/x01-003.

Mitchell, R.J., J.K. Hiers, J.J. O'Brien, S.B. Jack, and R.T. Engstrom. 2006. Silviculture that sustains: the nexus between silviculture, frequent prescribed fire, and conservation of biodiversity in longleaf pine forests of the southeastern United States. Canadian Journal of Forest Research 36: 2724-2736 https://doi. org/10.1139/X10-017.

Mitchell, R.., J.K. Hiers, J.J. O'Brien, and G. Starr. 2009. Ecological forestry in the Southeast: understanding the ecology of fuels. Journal of Forestry 107: 391-397.

Murphy, L.R. 2015. Likelihood: methods for maximum likelihood estimation. R package version 1.7. https://doi.org/10.1139/x06-1000.

Neel, L., P.S. Sutter, and A.G. Way. 2010. The art of managing longleaf: a personal history of the Stoddard-Neel approach. Athens: The University of Georgia Press.

Neel, L.K., and L.D. McBrayer. 2018. Habitat management alters thermal opportunity. Functional Ecology 32: 2029-2039 https://doi.org/10.1111/1365-2435.13123.

Nelson, R.M., and J.K. Hiers. 2008. The influence of fuelbed properties on moisture drying rates and timelags of longleaf pine litter. Canadian Journal of Forest Research 38: 2394-2404 https://doi.org/10.1139/X08-078.

O'Brien, J.J., J.K. Hiers, M.A. Callaham Jr., R.J. Mitchell, and S.B. Jack. 2008. Interactions among overstory structure, seedling life-history traits, and fire in frequently burned Neotropical pine forests. Ambio 37: 542-547 https://doi. org/10.1579/0044-7447-37.7.542.

O'Brien, J.J., E.L. Loudermilk, J.K. Hiers, S.M. Pokswinski, B. Hornsby, A.T. Hudak, D. Strother, E. Rowell, and B.C. Bright. 2016. Canopy-derived fuels drive patterns of in-fire energy release and understory plant mortality in a longleaf pine (Pinus palustris ) sandhill in northwest Florida, USA. Canadian Journal of Remote Sensing 42: 489-500 https://doi.org/10.1080/ 07038992.2016.1199271.

Ormeño, E., B. Céspedes, I.A. Sánchez, A. Velasco-García, J.M. Moreno, C. Fernandez, and V. Baldy. 2009. The relationship between terpenes and flammability of leaf litter. Forest Ecology and Management 257: 471-482 https://doi.org/10.1016/j.foreco.2008.09.019.

Outcalt, K.W., and D.G. Brockway. 2010. Structure and composition changes following restoration treatments of longleaf pine forests on the Gulf Coastal Plain of Alabama. Forest Ecology and Management 259: 1615-1623 https:// doi.org/10.1016/j.foreco.2010.01.039.

Pacala, S.W., C.D. Canham, J. Saponara, J.A. Silander, R.K. Kobe, and E. Ribbens. 1996. Forest models defined by field measurements: II. Estimation, error analysis, and dynamics. Ecological Monographs 66: 1-43 https://doi.org/10. 2307/2963479. 
Palik, B., R.J. Mitchell, S.D. Pecot, M.A. Battaglia, and M. Pu. 2003. Spatial distribution of overstory retention influences resources and growth of longleaf pine seedlings. Ecological Applications 13: 674-686 https://doi.org/10. 1890/1051-0761(2003)013[0674:SDOORI]2.0.CO;2.

Pecot, S.D., R.J. Mitchell, B.J. Palik, E.B. Moser, and J.K. Hiers. 2007. Competitive responses of seedlings and understory plants in longleaf pine woodlands: separating canopy influences above and below ground. Canadian Journal of Forest Research 37: 634-648 https://doi.org/10.1139/X06-247.

Pederson, N., J.M. Varner, and B.J. Palik. 2008. Canopy disturbance and tree recruitment over two centuries in a managed longleaf pine landscape. Forest Ecology and Management 254: 85-95 https://doi.org/10.1016/j.foreco.2007.07.030.

Prince, A., M.C. Chitwood, M.A. Lashley, C.S. DePerno, and C.E. Moorman. 2016. Resource selection by southeastern fox squirrels in a fire-maintained forest system. Journal of Mammalogy 97: 631-638 https://doi.org/10.1093/ jmammal/gyv210.

Provencher, L., B.J. Herring, D.R. Gordon, H.L. Rodgers, G.W. Tanner, J.L. Hardesty, L.A. Brennan, and A.R. Litt. 2001. Longleaf pine and oak responses to hardwood reduction techniques in fire-suppressed sandhills in northwest Florida. Forest Ecology and Management 148: 63-77 https://doi.org/10.1016/ S0378-1127(00)00525-9.

R Development Core Team. 2016. $R$ : a language and environment for statistical computing. Vienna: R Foundation for Statistical Computing.

Rebertus, A.J., G.B. Williamson, and E.B. Moser. 1989. Longleaf pine pyrogenicity and turkey oak mortality in Florida xeric sandhills. Ecology 70: 60-70 https://doi.org/10.2307/1938412.

Reid, A.R., and K.M. Robertson. 2012. Energy content of common fuels in upland pine savannas of the south-eastern US and their application to fire behaviour modelling. International Journal of Wildland Fire 21: 591-595 https://doi.org/ 10.1071/WF10139.

Ribbens, E., J.A. Silander, and S.W. Pacala. 1994. Seedling recruitment in forests: calibrating models to predict patterns of tree seedling dispersion. Ecology 75: 1794-1806 https://doi.org/10.2307/1939638.

Robertson, K.M., and T.L. Hmielowski. 2014. Effects of fire frequency and season on resprouting of woody plants in southeastern US pine-grassland communities. Oecologia 174: 765-776 https://doi.org/10.1007/s00442-013-2823-4.

Robertson, K.M., and T.E. Ostertag. 2007. Effects of land use on fuel characteristics and fire behavior in pinelands of southwest Georgia. In Proceedings of the $23^{\text {rd }}$ Tall Timbers fire ecology conference: fire in grassland and shrubland ecosystems, ed. R.E. Masters and K.E.M. Galley, 181-191. Tallahassee: Tall Timbers Research Station.

Roe, J.H., K.H. Wild, and M.S. Chavez. 2019. Responses of a forest-dwelling terrestrial turtle, Terrapene carolina, to prescribed fire in a longleaf pine ecosystem. Forest Ecology and Management 432: 949-956 https://doi.org/10 1016/j.foreco.2018.10.026.

Romero, C., B.M. Bolker, and C.E. Edwards. 2009. Stem responses to damage: the evolutionary ecology of Quercus species in contrasting fire regimes. New Phytologist 182: 261-271 https://doi.org/10.1111/j.1469-8137.2008.02733.x.

Thaxton, J.M., and W.J. Platt. 2006. Small-scale variation alters fire intensity and shrub abundance in a pine savanna. Ecology 87: 1331-1337 https://doi.org/ 10.1890/0012-9658(2006)87[1331:SFVAFI]2.0.CO;2.

van Altena, C., R.S.P. van Logtestijin, W.K. Cornwell, and J.H.C. Cornelissen. 2012. Species composition and fire: non-additive mixture effects on ground fuel flammability. Frontiers in Plant Science 3: Article 63 https://doi.org/10.3389/ fpls.2012.00063.

Varner, J.M., J.M. Kane, J.K. Hiers, J.K. Kreye, and J.W. Veldman. 2016. Suites of fireadapted traits in the southeastern USA oaks: multiple strategies for persistence. Fire Ecology 12: 48-64 https://doi.org/10.4996/fireecology.1202048.

Werner, P.A., and L.D. Prior. 2013. Demography and growth of subadult savanna trees: interactions of life history, size, fire season, and grassy understory. Ecological Monographs 83: 67-93 https://doi.org/10.1890/12-1153.1.

Whelan, A., S.W. Bigelow, M.F. Nieminen, and S.B. Jack. 2018. Fire season, overstory density and groundcover composition affect understory hardwood sprout demography in longleaf pine woodlands. Forests 9: $423 \mathrm{https} / / \mathrm{doi}$. org/10.3390/f9070423

Williamson, G.B., and E.M. Black. 1981. High temperature of forest fires under pines as a selective advantage over oaks. Nature 293: 643-644 https://doi.org/10.1038/293643a0.

\section{Submit your manuscript to a SpringerOpen ${ }^{\circ}$ journal and benefit from:}

- Convenient online submission

- Rigorous peer review

- Open access: articles freely available online

- High visibility within the field

- Retaining the copyright to your article

Submit your next manuscript at $\boldsymbol{\sim}$ springeropen.com 